\author{
Jarosław Poliszczuk* \\ Uniwersytet im. Adama Mickiewicza w Poznaniu \\ https://orcid.org/0000-0001-9081-7900
}

\title{
O klimatach podróżniczych i spotkaniach uniwersyteckich: wspomnienia Mychajły Najenki
}

\author{
[Rec. Mychajło Najenko, Ozon zarubiżż'a,
} Kijów 2019, ISBN 978-617-7625-99-4, 304 ss.]

Streszczenie: Artykuł zawiera szczegółowe omówienie oraz analizę pamiętników profesora Uniwersytetu Kijowskiego Mychajły Najenki, wydanych w ukraińskojęzycznej książce Ozon zagranicy (w wersji oryginalnej: Озон зарубіжжя, Kijów 2019). Lektura tekstu potwierdza, że jest to zdaniem recenzenta - publikacja będąca zarówno doskonałą relacją z podróży, zbiorem wspomnień, podsumowaniem drogi naukowo-twórczej uczonego humanisty, jak i dokumentem prywatnym, efektem wielu pytań, okazjonalnych sądów oraz głębokiego namysłu. Najenko ulega iluzji, której istota tkwi w symbolicznym odzyskiwaniu czasu. Przeszłość zostaje co prawda wyartykułowana w zwięzłej wypowiedzi, jednak autorowi wydaje się, że utracony czas dzięki prowadzonej narracji będzie on mógł odzyskać. Książka może się okazać przydatna czytelnikom pragnącym przewartościować własną przeszłość, poddać

Jarosław Poliszczuk - prof. dr hab., pracownik Zakładu Ukrainistyki Uniwersytetu im. Adama Mickiewicza w Poznaniu; ostatnio opublikował książki Reaktywność literatury (Реактивність літератури, Київ 2016) oraz Topografia hybrydowa. Miejsca i nie-miejsca we współczesnej literaturze ukraińskiej (Гібридна топографія. Місия і не-місия в сучасній украӥнській літературі, 2018). 
ją rewizji, konfrontując zarazem z aktualną rzeczywistością. Dzieło Mychajły Najenki wydaje się dobrym przyczynkiem do historii najnowszej, zwłaszcza w aspekcie postawy intelektualisty wobec wyzwań naszej niespokojnej epoki.

Słowa-klucze: narracja, autor, Ukraina, Europa Środkowo-Wschodnia, studia slawistyczne.

\section{On Travel Themes and Academic Encounters}

Summary: The article reviews the original book of memoirs of the Kiev University professor Mykhailo Naienko entitled "Ozone Abroad" (in the original version “Озон зарубіжжя"), published in Kiev in 2019. According to Naienko himself, his text is an excellent account of travel, a collection of memories, and a summary of the scientific and creative path of the scholar. It is also some kind of private document, the result of many questions, occasional judgments and profound reflections. Naienko succumbs to an illusion that time can be symbolically regained while the past is articulated and formed in a concise statement, the author feels as if the narrative would make it possible for him to get back to the lost time. Of course, this is an illusory. Reminiscences from the old times experienced by the author will probably be useful to others who want to redefine the past, subjecting it to revision and confronting it with current reality. Mykhailo Naienko's book seems to be a good contribution to modern history, especially in terms of the intellectual attitude to the challenges of our troubled age.

Key words: narrative, author, Ukraine, Central and Eastern Europe, Slavic studies. 
W ostatnich czasach dokonuje się niesamowite przewartościowanie literatury spod znaku non-fiction. Obecny świat wydaje się być przesycony informacją, zmęczony jej nadmiarem. Amerykański badacz Paul Stephens ów nadmiar wiadomości (information overload) określa jako typową cechę współczesności¹. Egzystująca w takim środowisku jednostka ludzka zostaje zmuszona do ucieczki spod nasilającego się potoku wiedzy powszechnej, ale jednocześnie poszukuje wiedzy niszowej, bardziej w jej mniemaniu odpowiedniej, pożytecznej. Na tym trendzie zyskuje literatura non-fiction, gdyż jest w stanie zaoferować czytelnikowi oryginalne spojrzenie na rzeczy dobrze, zdawało by się, znane. Znudzeni informacją, chętnie przecież spoglądamy na spontaniczne doświadczenie ludzkie, które zawsze zawarte jest w literaturze wspomnieniowej i pamiętnikarskiej i które, konkretnie rzecz ujmując, jest najważniejszym atutem takiej właśnie, niszowej twórczości. To, co urzeka nas we wspomnieniach, w sposób niespodziewany rzutuje na zrozumienie istoty - dawnej czy zupełnie nowej - historii, zwłaszcza w jej wymiarze humanistycznym i prywatnym, skonfrontowanym $\mathrm{z}$ wymiarem statystycznym, dostępnym w podręcznikach czy skryptach dziejów.

Wśród licznych wspomnień z niedawnej epoki na uznanie zasługują opinie intelektualistów, będących nie tyle świadkami „żywej” historii, ile jej bacznymi obserwatorami, zdolnymi do wnikliwej refleksji nad tym, co udało im się przeżyć i doświadczyć. Książkę Ozon zagranicy (Озон зарубіжжя) ${ }^{2}$ wypadałoby oceniać właśnie w takim kształcie - jako opowieść o zagranicznych podróżach oraz rzetelne prezentowanie doznanych wrażeń i przeprowadzonych refleksji. W takim układzie spełnia ona swoje zadanie, skłaniając czytelnika do rozważań na temat roli intelektualistów w transformacji ustrojowej Europy Wschodniej w okresie upadku komunizmu i kształtowania się nowych państw, odmiennych relacji w tym regionie. Rzecz jasna, autor nie jest skłonny do hiperbolizowania owej roli. Reprezentując środowisko uniwersyteckie, akademickie, Mychajło Najenko nie mierzy się z politykami bądź dyplomatami. Z innej zaś strony, charakterystyczne dla jego narracji jest to, że nie bagatelizuje wysiłku intelektualistów, pokazuje, na ile istotne

1 P. Stephens, The Poetics of Information Overload: From Gertrude Stein to Conceptual Writing, Minneapolis 2015, p. XIV-XV.

2 М. Наєнко, Озон зарубіжжя, Київ 2019. 
było zabranie przez nich głosu w kwestiach trudnych i niejednoznacznych, budzących kontrowersje.

Ale wróćmy do postaci samego autora. Profesor Najenko (Михайло Кузьмович Наєнко) jest wybitnym ukrainistą, teoretykiem i historykiem literatury, organizatorem życia naukowego, opiekunem młodych naukowców i literatów ukraińskich. Autor licznych prac naukowych, między innymi tak znaczących, jak: Pięciolecie powieści ukraińskiej (П’ятиліття українського роману, 1985), Epos romantyczny (Романтичний епос, 1988, 2000), Historia ukraińskiego literaturoznawstwa i krytyki (Iсторія украӥнського літературознавства і критики (2001, 2010), Literatura piękna Ukrainy (Художня література України, 2005, 2008, 2012) oraz wielu innych. Samo wyliczenie wszystkich jego prac zajęłoby dużo miejsca. Między innymi są wśród nich także tłumaczone na inne języki, na przykład wydana w języku słowackim książka o romantyzmie Ukrajinski literarni romanintizmus. Dobove a naddobove (2006). Za wybitne osiągnięcie badawcze, jakim była dwutomowa Historii literatury ukraińskiej (1994), w której po raz pierwszy zaprezentowano sylwetki ukraińskich pisarzy represjonowanych i zakazanych przez cenzurę sowiecką, Najenko został laureatem Narodowej Nagrody im. Tarasa Szewczenki (1996).

Trudno przecenić zasługi Mychajły Najenki w rozwoju studiów humanistycznych na najważniejszym uniwersytecie ukraińskim, który przecież w dobie niepodległości Ukrainy przeżywa prawdziwy renesans. W strategicznie ważnym okresie przejściowym, obejmującym lata 1992-2001, Profesor był dziekanem Wydziału Filologicznego tejże uczelni i to dzięki jego inicjatywom powstały na niej nowe kierunki, którymi szczyci się ona do dzisiaj i które znakomicie się rozwijają. Jako dziekan przyczynił się do rozkwitu badań slawistycznych, ściągnął do Kijowa wybitnych uczonych, w tym z zagranicy. Powołał nowe specjalności, w tym slawistyczne, których nigdy w Kijowie nie było, a które stały się odpowiedzią na zachodzące w Europie zmiany, na powstanie nowych państw (na Bałkanach po upadku Jugosławii czy po podziale Czechosłowacji w 1993 roku). Najenko zadbał także o rozwój studiów polonistycznych. Nawiązywał w swej działalności do zapomnianej tradycji Uniwersytetu Kijowskiego, zwłaszcza do przedrewolucyjnego seminarium prof. Wladimira Peretca (później członka Akademii Nauk Związku Radzieckiego, represjonowanego w okresie stalinowskim). Dzięki staraniom Profesora Naj- 
enki owo seminarium zostało odtworzone i przybrało kształt corocznej konferencji międzynarodowej, której materiały regularnie ukazują się drukiem. Ale największa chluba Mychajły Najenki to powołanie specjalności „Twórczość literacka" w roku 1998, która była kontynuacją i rozwinięciem idei słynnego niegdyś Moskiewskiego (wł. Wschechzwiązkowego) Instytutu Literackiego im. Maksima Gorkiego. Wśród licznych inicjatyw Profesora należy docenić jego starania skierowane do nawiązania ścisłej współpracy z wieloma placówkami uniwersyteckimi za granicą, przede wszystkim w regionie Europy Środkowo-Wschodniej, o czym w sposób oryginalny i bezpośredni autor opowiada $\mathrm{w}$ recenzowanej tutaj książce.

W listopadzie 2018 roku profesor Najenko obchodził jubileusz 80-lecia urodzin. $\mathrm{Z}$ tej okazji uhonorowano go prestiżowymi odznaczeniami podczas uroczystej akademii na Uniwersytecie Kijowskim im. Tarasa Szewczenki, uczelni, z którą związał swoją karierę naukowo-badawczą. Ów dostojny jubileusz to dobry powód, żeby się zastanowić nad skutkami wieloletniej pracy uczonego i popularyzatora nauki.

Najenko jeszcze kilka lat temu wydał tom wspomnieniowy Wieczorowe świty (Вечірні світанки, 2015)3. W tamtych wspomnieniach podsumowuje swoją drogę życiową konsekwentnie, począwszy od dzieciństwa i młodości, poprzez trudne lata reżimu sowieckiego, do spełnienia w okresie Niepodległości oraz Wolności. Doświadczenie to ciekawe i cenne, gdyż pokazuje ewolucję uczonego od naiwnych marzeń młodzieńczych do zrealizowania wielu odważnych pomysłów w latach 80 . oraz 90 . XX wieku, kiedy idea Ukrainy Niepodległej ucieleśnia się w życiu społeczeństwa ukraińskiego, a patriotycznie zaangażowani intelektualiści (wśród nich nasz autor - jako ukrainista nie tyle z zawodu, ile z przekonania i pasji) mierzą się z niebywałymi wyzwaniami. Ozon zagranicy w pewnym stopniu koresponduje z poprzednim tomem wspomnień Mychajły Najenki. Jest on naturalną kontynuacją zaprezentowanej poprzednio narracji oraz szczegółowym omówieniem tych zagadnień, które zostały pominięte.

Zagraniczne podróże autora bez wątpienia zasługują na osobną opowieść. Zarówno ze względu na ich przedmiot, reprezentujący bogate i rozmaite

3 Tegoż, Вечірні світанки: Берибіське Гуляйполе. «Від Києва до Лубен» і літературні візії, Київ 2015. 
wspomnienia o podróżach do różnych państw Europy i świata, jak i ze względu na aspekt podmiotowości, wyrażony oryginalnym spojrzeniem autora na sprawy użyteczne, wzbogacony opisami jego spontanicznych wrażeń bądź autoironicznych komentarzy wobec doznanych w czasie wędrówek przygód.

Nieprzypadkowo też książka została zatytułowana w taki sposób. Ozon, jak wiadomo, to pierwiastek posiadający silne właściwości aseptyczne oraz toksyczne. Toteż wyjazdy autora za granicę są traktowane we wspomnieniach jako momenty złapania świeżego oddechu przez doświadczenie inności w szerokim zakresie tego pojęcia. Nie da się ukryć, że owe wyprawy miały charakter pouczający, więc powrót do domu powodował, że autor poddawał weryfikacji własne poglądy, przede wszystkim stereotypy o zagranicy i „wrogim” Zachodzie, tak mocno wpojone niegdyś w świadomość obywateli radzieckich ${ }^{4}$.

Książka została ułożona w taki sposób, że osobne rozdziały nawarstwiają się w porządku chronologicznym. Są one poświęcone podróżom do krajów ościennych - Węgier, Czechosłowacji, Wschodnich Niemiec (wówczas NRD), Rumunii, Jugosławii etc. Jak wiadomo, możliwości podróżowania w okresie sowieckim były bardzo skromne i ograniczały się do krajów „ludowej demokracji”, czyli satelitów obozu ZSRR. W okresie późniejszym, tzn. w erze Niepodległości, autor odwiedza również kraje zachodnie - Austrię, Republikę Federalną Niemiec, Stany Zjednoczone Ameryki, Indie i inne. Dodaje do tego relacje z krajów, które od niedawna stały się „zagranicą”, jednakże pozostają mocno związane kulturowo z postsowiecką Ukrainą: są to państwa bałtyckie, państwa Azji Środkowej i Kaukazu, Białoruś oraz Rosja. Wspomniane wyżej trzy warstwy nierzadko zderzają się ze sobą, ale w gruncie rzeczy wyrażają istotę geopolitycznej transformacji całego naszego regionu doznającego we względnie krótkim okresie gwałtownych przemian cywilizacyjnych ${ }^{5}$.

Przeważnie relacje podróżnicze Mychajły Najenki są bezpośrednio związane z jego wyjazdami na konferencje oraz staże naukowo-dydaktyczne (Niemcy, USA, Czechy, Indie). Rzadziej opisywane są wędrówki turystyczne,

4 O znaczeniu miejsca w kształtowania tożsamości człowieka po upadku systemu komunistycznego piszę bardziej szczegółowo w niedawno opublikowanej książce: J. Poliszczuk, Гібридна топографія. Місия і не-місия в украӥнській літературі, Чернівці 2018.

5 Zob. T. Snyder, Droga do niewolności. Rosja, Europa, Ameryka, przeł. B. Pietrzyk, Kraków 2019, s. 16-18. 
aczkolwiek również zawierające pewne spostrzeżenia o charakterze poznawczym. Nie bacząc na taką specyfikę podróżowania z dominacją spraw służbowych, narracja pozostaje otwarta. Autor przecież nie ogranicza się do opisania realiów konferencyjnych, traktuje swoje pobyty jako pretekst do poznawania krajów, kultur, ludzi. Przydatne w tym kontekście stają się zdjęcia, obficie zamieszczone w książce, które nie tylko przedstawiają autora na tle egzotycznych krajobrazów (przyznajmy, że dosyć często właśnie to jest istotą zdjęć robionych w czasie wypraw zagranicznych), lecz utrwalają wybitne postaci nauki i kultury, o których opowiada Najenko.

Książka zawiera sporo wątków wartych dokładnego omówienia, choć forma zwięzłej recenzji nie pozwala na ich rozwinięcie. Zwróćmy więc uwagę czytelnika na dwie kwestie, ważne dla całokształtu wypowiedzi wspomnieniowej. Pierwsza dotyczy rozwoju badań slawistycznych i regionalnych w Europie po upadku komunizmu, druga charakteryzuje relację środowisk akademickich i kulturalnych Ukrainy ze współczesną Rosją. Wspominając trudne lata 90. XX wieku, Najenko podaje sporo wzmianek o tym, jak nawiązywały się nowe kontakty i przyjaźnie w postkomunistycznej Europie Środkowej i Wschodniej. Zresztą, sam autor był jednym z inspiratorów takich kontaktów, pełniąc stanowisko dziekana Wydziału Filologicznego czołowej uczelni kraju.

Początek lat 90. ubiegłego stulecia był w tym kontekście okresem bardzo trudnym (ale jednocześnie inspirującym i wydajnym): stare więzi straciły znaczenie, natomiast nowe dopiero powstawały, przy czym niekoniecznie na poziomie politycznym i dyplomatycznym. Przecież formowanie nowego państwa, jakim stała się niepodległa Ukraina, odbywało się w warunkach braku wyrazistej koncepcji państwa, nie mówiąc już o niedoborze kadry dyplomatycznej do obsadzenia placówek za granicą. W tej sytuacji, jak dowodzi profesor Najenko, bardzo istotną rolę odegrała dyplomacja lokalna, której sam autor był doskonałym rzecznikiem. Wspierając pomysły założenia na Uniwersytecie Kijowskim polonistyki, kroatystyki, bohemistyki bądź innych filologii obcych z obszaru europejskiego, intelektualiści ukraińscy jednocześnie dążyli do partnerskiej wymiany i otwierali na uczelniach zagranicznych odpowiednie placówki ukrainistyczne, tworząc w ten sposób nadrzędną zasadę równowagi $\mathrm{w}$ relacjach międzynarodowych na poziomie porozumień uczelnianych. W tym celu z Kijowa wysyłano lektorów języka ukraińskiego na cały świat. Inicjatywa Uniwersytetu Kijowskiego dała całkiem dobry rezultat, gdyż udało 
się dzięki temu wsparciu zorganizować studia ukrainistyczne w wielu krajach, w szkołach wyższych Zagrzebia, Sofii, Brna etc. Są one również w Polsce: na Uniwersytecie Warszawskim, Jagiellońskim i innych uczelniach. To przykład dobrej współpracy międzynarodowej i dyplomacji „,chodaczkowej” (o ile wypada tutaj użyć odniesienia do dawnej historii) w sytuacji, gdy państwo nie potrafiło działać skutecznie - czy to z powodu braku woli, braku kadry, czy środków finansowych. Kontakty bezpośrednie intelektualistów, świadomych racji stanu, w tym przypadku zaowocowały wzajemnym zaufaniem i budowaniem nowych więzi międzynarodowych w Europie po komunizmie. W dłuższej perspektywie to zjawisko rysuje się coraz bardziej obiecująco.

Kolejna kwestia, nie mniej skomplikowana, dotyczy stosunków z Rosją. Ciekawe, że sam autor przez wiele lat był aktywnym uczestnikiem sowieckiego życia intelektualnego, reprezentując w ramach tego dyskursu humanistykę ukraińską. Wówczas chętnie publikował w czasopismach rosyjskich, mających przecież najwyższy status jako czasopisma ogólnokrajowe (w Związku Radzieckim), wyjeżdżał na konferencje i sesje naukowe do Moskwy. Sytuacja uległa radykalnej zmianie w ostatnich latach, kiedy doszło do aneksji Półwyspu Krymskiego oraz wojny w Donbasie. Wzajemne napięcia w relacji Ukraińców i Rosjan stopniowo się nasilały, co widać chociażby w polemice intelektualistów na temat nadrzędnych kwestii spuścizny kulturowej. Zwłaszcza idzie tu o spadek historyczny Imperium Romanowów oraz Związku Radzieckiego, o system represyjny i ruch dysydencki w ZSRR, o światopogląd imperialny i kolonializm. Autor przytacza fragment referatu o twórczości Fiodora Dostojewskiego, który pokazuje skalowanie tego typu napięć i wzajemnych pretensji. Wobec tego całkiem logiczne stało się to, że w roku 2014 strona rosyjska, powiada profesor Najenko, nie przyjęła zaproponowanego przez niego tekstu. Zrezygnowała również z zaproszenia go do udziału w międzynarodowej sesji w Moskwie. Po tym Najenko opublikował kilka złośliwych felietonów na łamach gazet ukraińskich, obalając w nich racje propagandzistów rosyjskich, publikowanych w sławnej niegdyś moskiewskiej „Литературной газете”. Historia iluzji mówiącej o „przyjaźni narodów", która mocno utkwiła w świadomości wielu obywateli ZSRR, dobiegła końca. W recenzowanej tutaj książce zostało to ukazane na przykładzie konkretnej jednostki ze swoim własnym światopoglądem i bogatym doświadczeniem. 
Podczas lektury książki Najenki trochę przeszkadzało mi to, że autor zamieścił fragmenty wygłaszanych na konferencjach referatów. Wydaje się to posunięciem sprzecznym z samą istotą wspomnień, jak też naruszeniem gatunkowej struktury książki. Po dokładnym wczytaniu się w treść tych jego wystąpień zmieniłem jednak zdanie, zrozumiałem bowiem głębszy sens tego rozwiązania. Śledząc trasę podróży autora, czytelnik przecież przemieszcza się nie tylko w przestrzeni, ale również w czasie: od lat 80 . XX wieku po lata najnowsze, niosące ze sobą nowe cezury, kresy i rozgraniczenia - zarówno te zewnętrzne, kształtujące obszary przestrzeni geopolitycznej, jak i wewnętrzne, wyznaczające charakter narracji, modus retoryczny i ton wypowiedzi. Przytoczone fragmenty referatów naukowych, odczytywanych przez autora na spotkaniach sesyjnych w Europie czy Ameryce, dobitnie pokazują ewolucję światopoglądową samego autora, ale także dotyczą preferencji tematycznych i problemowych, wskazują na rozwój wiedzy humanistycznej w okresie późnosowieckim i pokomunistycznym. Między innymi, jeden z ostatnich rozdziałów poświęcony zostaje wyjazdom na Krym i relacjom z uczonymi krymskimi, przy czym autor nie bez nuty smutku konstatuje, że tak bliski mu półwysep, niegdyś ukraiński, niespodziewanie stał się zagranicą w 2014 roku.

Recenzowana książka Najenki skłania ku refleksjom nad radykalnymi zmianami, które zaszły w naszej części Europy i które wyraźnie rzutują również na zmianę paradygmatu w naukach humanistycznych, w tym naukach o literaturze pięknej. Rzeczywiście, dokonało się coś wielkiego. Wybitny amerykański historyk, Timothy Snyder, ujmuje to w kategoriach myślenia posthistorycznego oraz cyklicznego. Przekonuje o upadku myślenia w kategoriach nieuchronności, które wymuszało prosty sposób doświadczania czasu. W zamian przychodzi inne - jeszcze niezupełnie wyklarowane - doświadczenie, które kształtuje odmienne postrzeganie świata po upadku komunizmu:

Amerykanów i Europejczyków przez nowe stulecie prowadziła opowieść o końcu historii, coś, co dalej będę nazywać myśleniem w kategoriach nieuchronności: poczucie, że przyszłość jest po prostu przedłużeniem teraźniejszości, prawa postępu są znane i nie ma alternatywy, a zatem nic tak naprawdę nie trzeba robić. W kapitalistycznej amerykańskiej wersji tej opowieści natura przyniosła rynek, rynek demokrację, a ta z kolei szczęśliwość. W wersji europejskiej historia przyniosła naród, który z wojny wyciągnął lekcję, że pokój jest dobry, i dlatego wybrał 
integrację oraz dobrobyt. [...] Amerykańskie myślenie w kategoriach nieuchronności, podobnie jak wszystkie takie opowieści, było odporne na fakty. Losy Rosji, Ukrainy i Białorusi po 1991 roku pokazywały wystarczająco dobitnie, że upadek ustroju nie pozostawia pustej przestrzeni, w której natura buduje rynki, a te z kolei tworzą prawa6.

Jak to często bywa z literaturą wspomnieniową, autor Ozonu zagranicy ulega iluzji, której istota tkwi w symbolicznym odzyskiwaniu czasu. O ile przeszłość zostaje wyartykułowana i uformowana w zwięzłej wypowiedzi, o tyle wydaje się autorowi, że „cały czas stracony stanie się czasem odzyskanym”7. Oczywiście, to ujęcie jest złudne. Nic nie powróci, a przeżyte przygody z dawnych czasów przydać się mogą wyłącznie jako narracja, która na nowo dowartościowuje przeszłość, poddając ją rewizji i konfrontując z rzeczywistością aktualną.

Lektura recenzowanego tekstu potwierdza, że jest on zarówno doskonałą relacją z podróży, zbiorem wspomnień, podsumowaniem drogi naukowotwórczej uczonego humanisty, jak i dokumentem prywatnym, efektem wielu refleksji, okazjonalnych sądów oraz namysłów. W tym sensie symboliczne odzyskiwanie czasu przeszłego autorowi się udało. Książka Najenki wydaje się dobrym przyczynkiem do historii najnowszej, zwłaszcza w aspekcie badania postawy intelektualisty wobec wyzwań naszej niespokojnej epoki.

\section{Bibliografia}

Dąbrowski B., Przypadłość archiwum. Fikcja dokumentu w narracjach o Zagładzie, [w:] Narracje po końcu wielkich narracji: kolekcje, obiekty, symulakra, red. H. Gosk i A. Zieniewicz, Warszawa 2007.

Najenko M., Ozon zarubiżżia, Kyjiw 2019.

6 Tamże, s. 16.

7 B. Dąbrowski, Przypadłość archiwum. Fikcja dokumentu w narracjach o Zagładzie, [w:] Narracje po końcu wielkich narracji: kolekcje, obiekty, symulakra, red. H. Gosk i A. Zieniewicz, Warszawa 2007, s. 246. 
Najenko M., Weczirni switanky: Berybiśke Hulajpołe, «Wid Kyjewa do Łuben» iliteraturni wiziji, Kyjiw 2015.

Poliszczuk J., Hibrydna topohrafija. Miscia i ne-miscia w ukrajinśkij literaturi, Czerniwci 2018.

Potasińska P., „Jak pisarze pamiętają". Teoria badań nad pamięcią a praktyka literacka. Trzy "retoryki odtworzenia”, [w:] Świadectwa pamięci. W kręgu źródeł i dyskursów (od XIX wieku do dzisiaj), red. E. Dąbrowicz, B. Larenta, M. Domurad, Białystok 2017, s. 25-49.

Snyder T., Droga do niewolności. Rosja, Europa, Ameryka, przeł. B. Pietrzyk, Kraków 2019.

Stephens P., The Poetics of Information Overload: From Gertrude Stein to Conceptual Writing, Minneapolis 2015. 